\title{
Too Many Webers for Small Sociology; or, How Critically Sociologists Should Consider Their Canon*
}

ALLEN K. (2017). WEBER: SOCIOLOGIST OF THE EMPIRE. LONDON: PLUTO PRESS. 224 P. ISBN 978-0-74-

533744-9

\author{
Irina Trotsuk \\ Doctor of Sociological Sciences, Leading Research Fellow, Centre for Fundamental Sociology, \\ National Research University - Higher School of Economics \\ Senior Research Fellow, Center for Agrarian Studies, \\ Russian Presidential Academy of National Economy and Public Administration \\ Professor, Sociology Chair, Peoples' Friendship University of Russia (RUDN University) \\ Address: Myasnitskaya str., 20, Moscow, Russian Federation 101000 \\ E-mail: irina.trotsuk@yandex.ru
}

It is always a challenge to reflect on a book which is definitely beyond your "institutional" field of competence. I am not sure the situation is the same in all "national" sociologies ${ }^{1}$, but being a Russian sociologist means having a distinct field of competence - acquired or ascribed by the "significant others" of the sociological community. There have been many debates on the relevance of any sociologists' typology, however strange the very idea of such a typology is. For example, in the Russian sociological tradition, such typologies vary from the bitter-ironic one introduced by Gennady Batygin to the generally acknowledged one presented in the collection of essays Debate on Methods (Voronkov et al., 2004). The former proposed a distinction between "service" sociologists (striving for administrative power), "hunting" sociologists (searching for new knowledge) and "decorative" sociologists (creating communicative networks) (Batygin, 2002) based on some more "traditional" typologies, such as developed by Vickery and Vickery $(1987){ }^{2}$ Debate

(C) Irina Trotsuk, 2019

(C) Centre for Fundamental Sociology, 2019

DOI: $10.17323 / 1728-192 \mathrm{X}-2019-2-189-201$

* The results of the project "Between Political Theology and Expressive Symbolism: The Discursive Formations of the Late Modernity as a Challenge to the Social Order" carried out within the framework of the Basic Research Program at the National Research University Higher School of Economics (HSE) in 2019, are presented in this work.

В данной работе использованы результаты проекта «Между политической теологией и экспрессивным символизмом: дискурсивные формации позднего модерна как вызов социальному порядку», выполняемого в рамках Программы фундаментальных исследований НИУ ВШЭ в 2019 году.

1. Certainly, there are such schools despite all globalization trends. I will miss all other debates - on the relevance of the very term 'sociology," on the distinction of sociology and social sciences, and many others that do exist and are worth mentioning but not focusing at in the review.

2. There are many more typologies, one of the most famous is presented in Berger's Invitation to Sociology (1963), but there is no point in further focusing on the details to the detriment of the very idea of typology. 
on Methods was intended to reveal the senselessness and futility of the division between "quantitative" and "qualitative" sociology/methodology/studies but turned into a discussion about the epistemological grounds and heuristic potential of sociology in the spirit of Thévenot and Boltanski's (1983) idea of scientific interpretations as inevitably determined by social representations. Debate on Methods identified sociologists as theorists, methodologists and empiricists, and argued that the works of Weber were absolutely essential for theorists and methodologists of the "qualitative" camp (namely Weber's "interpretative sociology").

One can wonder why a review on a book on Weber starts with a description of the typologies of sociologists. My first explanation is that despite being a young discipline compared to other social sciences, sociology is extremely diversified and rife with inner distinctions. This leads to the situation that when we study to become sociologists we usually have a very brief and general overview of all the classical works (the canons differ but Weber is omnipresent) and then focus on some classical ideas taken out of the context of their works and time. For example, if you focus on qualitative approach, you will study Weber's "theory of action" and "theory of interpretation" as the purely methodological foundations of empirical work; if you are more interested in management, you will study Weber's "theory of power" and "theory of bureaucracy" as providing key ideas and notions for the analysis of contemporary systems of control and governance, and so on. Therefore, officially Weber is a kind of a 'sacred canon" for the theory and history of sociology (let us be honest and admit that not too many sociologists want to specialize in both for different reasons, including financial), but in empirical and applied research there seems to be many different Webers to justify our different terms, hypotheses, interpretations and forecasts.

My second explanation is that the book of Kieran Allen is great not only in the analysis of the Weberian legacy and tradition (of both admiration and criticism) but also in underlying and eliminating divisions between sociologists and within sociology. Before I make myself clear on both points, I have to warn the reader that this review is an extremely (undeservedly and even offensively) general and short enumeration of the book's ideas. This is not surprising given that the book "arises from an experience of teaching a course on classical sociology to first year students for over 20 years" (p. vii). Moreover, it would be strange to retell in the review all basic and well-known ideas of Weber as they are presented in the text. The book provides all necessary introductory information for a student who wants to be aware of the ideas and role of Weber in contemporary sociology (the author's task set in the Preface); explains the necessity for a critical reexamination of the traditional interpretations of Weber's ideas in the context of his own works and biography (in the Introduction); focuses on the historical and ideological context of Weber's life (in the first chapter); devotes another eight chapters to the justification and detailed clarification of the ways for the proposed critical reexamination of Weber's legacy as applied to his different theories (the spirit of capitalism, Asian underdevelopment, methodological issues, social and political differentiation, power and bureaucracy, the fall and rise of the West, capitalism and socialism, war and revolution); and makes some final 
conclusions and provides a bibliography and suggestions for additional reading. It is a complete course for sociology students. The review presents the book's key ideas and explains why its special combination of findings and weaknesses makes the book definitely worth reading.

In the Preface, Allen argues that numerous standard textbooks present "a similar package" of Weber's key ideas as the canon of sociology, which certainly provides younger generations of sociologists with "some pearls of wisdom" and "insights into modern society" but does not teach or encourage them to critically examine Weber's ideas especially because they hide his political agenda. The Introduction explains the reasons for the dominant "traditional" perception of Weber's legacy. One of them is the implicit typology of sociologists based on the idea of "an objective social science" (perhaps, the most questionable claim of our discipline). Allen identifies two groups of sociologists: the first profess sympathy with the left or radicals, for instance, denouncing corporate capitalist globalization and becoming radical critics of the social system (like Bourdieu); the second support the existing framework of society and offer advice on how best to adapt to the new challenges posed by globalization (like Giddens and Beck) (p. 2); and the question is who wins in interpreting the past and present.

According to Allen,

sociology is mainly a site for conflict about interpretations about society. It may profess to be non-political - to focus on wider social trends rather than immediate political issues [the question arises on the author's definition of "political" as opposed to "social"] — but it nevertheless deals with issues that people passionately fight over. Sociologists often adopt a non-political guise because of the pressure of their jobs and careers - even as they make the most outrageously political statements. Many of the disputes within sociology occur at a highly abstract theoretical level, often surrounded by the most forbidding jargon. However, in their complex and confusing ways, they often reflect debates in the wider society about whose interests should be served or which direction society needs to go in. (p. 2-3)

Allen argues that Weber made clear political statements and never hid them under any pressure, but they were ignored by his translators, propagators and interpreters especially under the prevailing opposition of Weber by another founding father of sociology Marx - who provided an equally comprehensive overview of modern capitalism.

The writings of both founding fathers lack the typical present-day data of detailed quantitative and qualitative studies, present grand searches for what constituted the fundamental dynamics of modern society, reflect interpretations of relative strangers not accustomed to capitalist societies, and ignore any rigid divisions between different academic subjects, thus, "reaching for the totality of expertise of life under capitalism" (p. 3). However, unlike Weber, Marx managed to maintain his political context due to his open advocacy of revolt and links with the socialist movement, and such a clear political emphasis together with his economic reductionism allowed Weber to win the debate within classical sociology. Allen provides the following comparison ensuring the victory of Weber as a "sophisticated doyen of value-free sociology" (p. 4): Weber advocated a complex 
multi-class model, Marx advocated a two-class model; Weber appreciated multi-factoral causation, Marx appreciated economic determinism; Weber warned of the impeding danger of bureaucratization, Marx had naïve hopes for a better world; Weber focused on the complexities of modern society, Marx advocated revolution. Moreover,

Weber's sociology fits in more easily with a form of academic learning which defines itself as neutral while disguising its own hierarchies and biases. ... Weberian sociology can recognize the existence of social conflict - but it can also imply that there is no need to challenge the wider system. ... Weber's overall pessimism, which assumes that domination of human beings by fellow human beings is inevitable, enables sociologists to make a critique of society - but also to imply there is little prospect of overall systemic change. All of this cuts the link between the critical knowledge and political action - and that is extremely helpful to a purely career-minded academic. (p. 4)

Allen emphasizes that our abstract apolitical reading of Weber's texts and our earnest ignorance of his openly declared and passionately expressed political views doe not make Weber a value-free sociologist: "Weber was an ardent German nationalist and a free market liberal ... the packaging of the academic Weber began after his death and owed much to mainstream American sociology" (p. 5). Allen reconstructs the main steps of this packaging: Weber's minimal influence in Germany immediately after his death; the activities of three key figures that determined the growth of his influence - his wife's Marianne editing of the collection of his works and the writing of his standard and basic biography, which aimed to construct a great man; after the Second World War, Winckelmann's selective assembling of Weber's works as representing an alternative account of historical development to Marx ("eliminated all polemic writings . . . to put together a timeless piece of value-free sociology"); and in the Cold War era, Parsons's reference to Weber's works as representing the classical European tradition and supporting Parsons's construction of "a grand theory that focused on how common values and norms helped to generate a stable and ordered society." Finally, in the late 1930s, "Parsons helped place Weber at the head of the sociological canon, suggested that Weber was 'fighting ... against the positivistic tendencies of Marxian historical materialism'. ... played down Weber's emphasis on power relations, ... and, in brief, Americanized Weber" (p. 7-8).

The Americanization of Weber was continued by Shils, who praised Weber as prophetic in warning against bureaucratization, as a classic free market liberal and a supporter of the American way before his time; by Bell and Lipset, who found arguments for their concept of the "end of history" in their particular interpretation of Weber's pragmatic grounds of rationality, efficiency and realism as suitable for many former left intellectuals; by Mills, who helped to establish Weber as the founder of the theory of stratification and domination, emphasizing certain aspects of Weber's writings to make them seem more left-wing liberal than they really were, and together with Gerth "presented Weber as a more sophisticated sociologist who had corrected Marx's lack of emphasis on human freedom ... and represents humanist and cultural liberalism rather than economic 
liberalism, ... Weber's deep pessimism about the possibility of changing capitalism and his ambiguous critique of its cold, bureaucratic machinery had a strong appeal to intellectuals" (p. 10).

Once Weber acquired such a dominance in American sociology, it allowed the reestablishment of his reputation in Germany and his canonization as the main classical sociologist of the free world was complete. Later his reputation was challenged by student revolts and the radicalization which revived some Marxist ideas and by academic studies which revealed his strong German nationalism (Mommsen), inherent elitism of his critique of popular democracy (Hirst) or implacable opposition to socialism (Bottomore). Nevertheless, especially after the collapse of socialist regimes, which convinced many academics in having no alternative to capitalism, Weber achieved a near hegemonic status: "In brief, Weber had become the touchstone for many modern theorists who accept the inevitability of capitalism and impossibility of change. More than that, he had become the fountainhead for the established wisdom of sociology itself" (p. 12).

After the Introduction, the rest of the book is devoted to fulfilling the author's intention to offer both an introduction to Weber by summarizing his arguments on different issues and critiques of his ideas as belonging to a sophisticated ideologue for capitalism. Thus, Weber is presented as a sociologist of empire who not only describes the historical development of capitalism but also defends it as the best of all possible worlds, albeit on the grounds of tragic necessity. Allen "removes the conventional packaging in which Weber was wrapped and looks at his writings in their actual context" to reveal that throughout his life Weber was concerned with three central issues: "One was the question of empire: why was imperialism in Germany's interest? The second was the leadership of Germany: after its unification, who was to lead the German nation? Finally, there was the question of class division and the rise of Marxism: how best was Marxism to be combated?" (p.15). While finding answers to these questions in Weber's writings, Allen comes to the conclusion that he saw himself as a "bourgeois scholar" and wanted Germany to be a great power, which determined the combination of sociology and political commentary in Weber's writings and made his imperialism "militant, direct and above all realistic" engaging in cold calculation about what was necessary for Germany to become a great power (p. 20).

Allen argues that Weber

assumed that Africans were "kulturlos" and could be legitimately colonized. He criticized Bismarck's "accommodating policy" of forging diplomatic alliances because it was "disinclined to all thoughts of overseas expansion." He supported von Tirpitz's plans to break from the traditional Prussian restraint in naval matters and develop a battle fleet that could challenge Britain's... Weber believed that imperialism was in the direct interest of German industry. He claimed that the expansion of trade "must now once more lead to a situation in which individual nations will share in economic control of the world." He persuaded his close associate Naumann to move from a Christian socialist outlook to one that embraced national power politics and imperialism. In a speech in 1896 on unemployment, Weber spelled 
out explicitly his rationale: "It is a vital matter for us that the broad masses of our people should become aware that the expansion of Germany's power is the only thing which can ensure for them a permanent livelihood at home and the possibility of progressive improvement." (p. 20-21)

According to Allen, Weber's sole concern was the interest of the German nation state; therefore, even his support for democracy was subordinate to his aim of expanding Germany's sphere of influence:

He saw the parliament primarily as an institution that was best suited to fulfilling the function of training a leadership that could avoid the irresponsibility and capriciousness of the German monarchy ... and provide a mechanism to conciliate the working class and win them to an imperialist outlook. ... Weber's central theme was that [German] national greatness had to be fought for rather than assumed. Generalizing from the imperialist culture of his age, Weber assumed that the struggle between peoples was the key feature of human life... . Weber made no bones about his view of academic science: "The ultimate goal of our science must remain that of cooperating in the political education of our nation." By political education he meant a mission to lead the German empire. (p. 22, 24, 26)

Nevertheless, Allen admits that Weber was brilliant enough to focus at the same time on the "disjunctures - between economic resources and political will, between the stability guaranteed by bureaucracy and the need for leadership to overcome its inertia, between the grandeur and bluster of empire and the need for sharp, realistic assessment of how to win" (p. 26).

Allen argues that Weber had no sympathy with socialism, saw the advocacy of an equal society as utopian, regarded any independent working-class politics with suspicion, and expected militant action by the working class to undermine progress including by pushing the elites in reactionary directions that would strengthen the old regime. So, despite being an acute observer of his society (he was one of the few commentators outside the ranks of the far left to predict the integration of the Social Democratic Party into German society in the war years), Weber "presented Marxist ideas implicitly as crude, one-sided and lacking the sophistication necessary to analyze complex societies" (p. 30). According to Allen, Weber defended the use of scientific and academic methods, but his very sociology generalized from the political polemics he was engaged in, therefore, his sociological writings should not be considered timeless and devoid of context.

Weber sought to awaken the German bourgeoisie to a sense of its heroic mission by romanticizing the origins of capitalism and creating an image of a moral and honest entrepreneur (the story of slavery, the theft of common lands, the ruthless economic terrorism used to turn peasant into workers virtually disappeared). He naturalized the imperialist outlook of his day by blaming the religious cultures of colonized countries for their colonization. More fundamentally, his peculiar view of rationality conveyed an impression that capitalism and bureaucracy were inevitable. (p. 173-174) 
Another of Allen's claim about Weber is that he explained and romanticized the Western spirit of capitalism by a simplistic standardization of Protestantism around a particular ideal model of belief and by the readings of social action from religious texts (i.e. modern capitalism was established in Western Europe by modest, dour, determined moral men with a mission) without explaining how the Reformation became successful. Allen continues: Weber explained how the affinity between Protestantism and capitalism worked in an inadequate chronological order, ignoring indications that capitalism had begun to expand inside the framework of feudalism before the 17th century, and providing no satisfactory explanation for how early capital was accumulated. He presented capitalism as a by-product of rationalizing forces without mentioning "the brutal role of force in accumulating capital, in imposing new disciplines on labor and in subjecting the colonies to the economic needs of the metropolitan countries" (p. 45).

Allen gives examples of China and India to underline Weber's romanticization of Western capitalism and European imperialism: he presented both countries as unchanging societies, imprisoned in a cultural time warp until colonialism arrived. As was typical for European societies of his time, Weber did not admit the economic developments of China before the mid-17th century (see: Pomeranz, 2000); in India, he assumed the rigid caste system to be primordial rather than the outcome of the complex relations between colonial intervention and indigenous tradition, describing Indian society as if it needed imperialism to attain peace and not to turn into a chaotic mass of tribal conflicts, and Weber never mentioned the destructive and retarding impact of colonization on India's development. According to Allen, it is this legacy of Weber that allowed (and still allows) developed countries to blame the cultures of underdeveloped countries for their failure to modernize, and it is this legacy that helped to construct the "modernizationdependency" debate and became a classic example of what later came to be referred to as Orientalist discourse.

Concerning methodology, Weber is presented in the book as (1) a methodological individualist, who generalized economic marginalism into a meta-theory of society and "smuggled the methods of conventional economics into sociology" (economic examples and ideal rational economic actors, who have full knowledge of their future needs and the resources available) instead of focusing on social structure; (2) a scholar of his time who tried to stand on very slippery slope of "marrying a subjective focus on values with the desire for objective methodological rigor" (p. 76), or of "navigating the rapids between the traditional German idealist emphasis on the active mind creating reality and the requirements of modern research" (p. 75); (3) a creator of the theory of rationality, who used three different definitions of it; and (4) an author of careful formal definitions and typologies filled at random from very diverse phases of history [we all tend to do that, at least when explaining complex phenomena to our students]. For example, Weber's charismatic leaders include bounty hunters, monarchs and revolutionary socialists from the dawn of time to the early 2oth century, which Allen considers irrelevant for scientific discourse; however, this is relevant if we take Weber's typologies as requiring historical clarifications 
(charismatic leaders in different times needed different qualities to be perceived as charismatic). Allen concludes that

\begin{abstract}
Weber's calculating rational man ... is by no means a neutral figure.... He acts according to the abstractly formulated psychology of the calculating individual agent of capitalism. Where ... the people do not follow this calculating culture, Weber steps down from his academic chair, to pronounce that they are "not of this world." In other words, the psychology of the sober bourgeois is the norm - all else is interesting but entirely ineffective. (p. 8o)
\end{abstract}

Weber's sociology is defined rather as ideological (supporting the First World War, deeply hostile to the growth of the revolutionary left in the aftermath of Germany's defeat, etc.) than as offering an objective value-free account of modern society. Allen argues that the problem is not so much that Weber's multi-class model won over Marx's twoclass model but that Weber's stratification theory dismisses the Marxist idea of exploitation, thus, supporting capitalism by directing class analysis to the normative concerns centered on the interest of capitalists - efficiency and rationalization. Such ignorance

\begin{abstract}
played down the role of masses of people in bringing change. The dialectic of history, for Weber, was torn between bureaucratization and charismatic leaders who acted as spellbinders for a passive population. Revolts of whatever kind - particularly those in highly-bureaucratisized societies - simply did not figure in his vision. . . . His implicit contempt for the self-activity of masses of "ordinary people" led to an overarching pessimism that ultimately justified an acceptance of capitalism and bureaucracy. (p. 178)
\end{abstract}

According to Allen, Weber is believed to have developed a powerful intellectual alternative to Marx's historical materialism, but Weber's sociology presents the rationality of the West as the end point of history, which "only emerged because of a combination of necessary elements, and no one element in this combination is deemed to have a causal primacy - it is the combination as a whole that counts" (p. 123). This is the only reference in the book to Collins's Weberian Sociological Theory (1986: 35) saying that "this makes world history look like the result of configurations of events so rare as to appear accidental." In the section on Additional Reading Allen calls Collins "Weber's hugely sympathetic follower" for his interpretation of Weber's theory of history (p. 201) and does not approve or accept such a "too sympathetic" presentation of Weber's legacy.

Moreover, according to Allen, Weber's main objections to the socialist experiment in Russia (he did not believe that the Bolsheviks could hold power) were determined primarily by his theory of bureaucracy as unbeatable.

Instead of assuming that bureaucracy was inevitable, an alternative method might be to analyze the specific historical circumstances of Russia to see why its revolution failed. Thus, one might look, for example, at how bureaucratic tendencies grew from Russia's international isolation, the destruction wrought of the country by the civil war and the conflicts that arose between the peasantry and the urban workers. ... Weber makes no distinction between the different types of bureaucracies 
that emerge in workers" movements and in wider society. ... He assumes apathy is a permanent state of affairs and can simply not explain how the process of revolt is possible. (p. 149, 153)

Allen reproaches Weber for considering as real actors only the elites, the charismatic heroes and the leaders of great states who enforce their domination; however, this is one of the well-known types of the theory of elites, so Weber just provided his own explanation for it in his theory of domination and bureaucracy.

In conclusion, it would be fair to apply the critical approach suggested by Allen to the very book that insists on its indiscriminate application to any sociological work. Unfortunately, I am not an expert in Weber's legacy and cannot critique the details or completeness of his biography, selected works or interpretations, especially taking into account that this is a very small book with the very big goal of presenting a comprehensive overview of Weber's key theories and critics - the text inevitably misses some names and points. Nevertheless, there are some obvious questionable assumptions and overly strong conclusions.

First, being so insistent in revealing the hidden and ignored ideological foundations and content of Weber's theories, Allen becomes as radical in the politicization of Weber's writings as the authors whom Allen criticizes for their radical de-politicization. This begs the questions: what are the limits for taking into account the political-ideological context of scholar's biography to explain their scientific views? Who has the right to set such limits? How unchangeable should they be when: (a) the scholar is alive and can enter the debates, (b) their contemporaries and colleagues can speak on their behalf, and (c) we find ourselves in completely different times providing us with nothing other than multiple interpretations and critical discourse analysis persuading us to consider every "text" within its discursive and social contexts (see, e.g., Fairclough, 1993), although both are impossible to reconstruct "from within" and unambiguously? When mentioning that students are not encouraged to "be overly critical of Weber," Allen does not provide necessary or sufficient criteria for criticism. For example, the proposed focus on the imperialistic dimension of Weber's ideas would be too politicized for a scholar who believes that Weber exaggerated the methodological individualism.

In Weber's time, a public intellectual possessed much more "totality" than scholars today. The latter should be aware of their different affiliations (and their requirements) when presenting their data and interpretations, and they should change their presentations for different audiences: for administration, scientific foundations, students, decision-makers who require clear recommendations without too much science-theory-methodology, and for a wider audience - as an expert speaking about some situation in general or evaluating a particular problem that affects his everyday life, and for his colleagues friends and opponents. All these contexts today (but not in the times of Weber) imply different types of publicity, demand different types of discourses and allow different levels of ideological enrichment. In other words, today one might give different lectures on Weber's theory of power to experts on Weber, to sociology students, to students of arts or 
engineering, to politicians at the round table on national social-economic strategy, and to a wider television audience (for example, Allen's term "the ruthless economic terrorism used to turn peasant into workers" does not seem appropriate for a scientific debate).

Weber could have been mistaken, as we all can be in the pressing social context, and Weber's "imperialistic" desire to expand his country's sphere of influence is more or less typical for all of us (there are many "nationalistic" directions in political and scientific circles today). So, Allen's emphasis on Weber's ideological mythologization often seems a bit much, especially taking into account that "Weber's aggressive nationalism did not blind him to the sources of German weakness" (p. 25) or that Weber was "an acute observer of the political scene" (p. 29); however, this emphasis is relevant for Weber's devoted admirers who purposefully ignored or hid excerpts of his writings. To define Weber as solely a "sociologist of empire" is also too strong. Today the word "empire" is often used as a name for a "natural" and "positive" social phenomenon presented in different ways because most peoples lived in empires throughout human history and, despite the bad reputation of empires, they often "promoted peace and prosperity" (see, e.g., Lal, 2004).

Allen insists that Weber's writings should not be considered timeless and devoid of context but sometimes does not follow this rule. For example, despite admitting that Weber "avoided the cruder forms of racism which were common at the time" (p. 54), Allen accuses him of "colonial imagery" and of the "deeply condescending and offensive tone of a shrill confident European imperialist to the people of India" (p. 53). Weber is not to blame for the European imperialist-orientalist discourse of his time, which was based on colonial administrators, missionaries and travel descriptions and focused on the historical and ahistorical study of other cultures' past through religious aspects detached from social evolution (and we still witness this discourse's discriminatory manifestations today). It is hard to imagine that Weber could oppose this discourse instead of reproducing it or that he could criticize the social construct of "traditional India." It is not fair to call Weber a racist and to say that "his more "educated" speculations about Chinese culture are even worse than the casual racism of the missionaries" (p. 63), because the very understanding of racism today differs greatly from Weber's time, when it was a social norm for both the "educated" and missionaries (though the latter should have been educated too). Certainly, Weber and "many German gentlemen" possessed "an imperialist disposition," but many English, French and other gentlemen and ladies also painted India and China (and many other countries) in dark colors as stagnant, passive, eternally "traditional" societies just because they believed in such a world due to their time's dominant discourses.

Second, Allen sometimes makes statements that are too strong. Some of them are rather idealistic, for example, that students who enroll in courses in sociology have a sense of unease about the growing violence and inequality and want to study how the world functions to change it for the better; or that social scientists can be divided into radical critics and supporters of any system (the division is much deeper, and one can criticize some aspects of the social system but devotedly support other its features); or that Weber's theory, cutting the link between critical knowledge and political action, is 
extremely helpful to a purely career-minded academic - career trajectories depend on the social context, so political actions (both critical and supportive) can be a direct path to academic career (today authoritative regimes establish sociological centers as if to study public opinion but in reality to affect it).

Some of Allen's other statements are too critical, for example, when he compares Weberian and Marxist traditions and criticizes the dominance of the former as due to a specific interpretation and academic support (according to Feyerabend (1975), this is the normal model of scientific development, so the problem is not limited to the WeberMarx intellectual dichotomy); or that Weber "became a valuable icon in the Cold War - an intellectual giant who rivaled and surpassed the USSR's championship of Marx" (p. 8) and even "an effective ideological tool ... not confined just to the conservative right" (p. 9); or that "academic practitioners of sociology" prefer to discuss on television some strange correlations (crime and "family breakdown") instead of the economy or changes in the political spectrum (today, the fact that lay knowledge ousts expertise from the public space is a general and not purely sociological problem); or that "no value-free sociology is possible in a world where the production of ideas is linked to the dominance of capital" (p. 13).

Such "exaggerations" are determined by the author's too ambitious aim to provide a brief but comprehensive introduction to Weber's legacy and at the same time an overview of all the accumulated critiques of it. The book cannot be called an "anti-Weber manifesto" for there is a good balance of acknowledgements and claims in the text; however, the author's overestimation of the importance of politically engaged inquiry into modern capitalism sometimes blurs the dividing line between a clever politician and an interested scholar, and questions the very definition and status of sociology.

This is a great book that is worth reading by every sociologist. Because the author's aim is absolutely different, by no means can the book be considered a part of the disciplinary fight for the "right interpretation" of Weber's substantive studies and methodological principles (see, e.g., Scaff, 1984: 191), or a part of the attack on the idea that Weber was a sociologist or a founding father of sociology (see, e.g., Turner 2002: 231), or a part of the critique of Weber as a subjectivist or bourgeois, to defend Marx as the scientist of social formations (see, e.g., Turner, 1977), or, on the contrary, as a part of the admiring tradition arguing that Weber's macro-sociological theory provides a more general and systematic view of history and society (see, e.g., Collins, 1986, who emphasized the potential of Weberian sociology in the analysis of the "world-system" model within the geopolitical approach) than the legacy of Marx's political economy. ${ }^{3}$ The book eliminates

3. According to B. Turner (1999: 11), the debate between Marx and Weber was much more controversial and incomplete than the supporters of either of the two try to present it, and it has been repeatedly transformed in different intellectual contexts. However, this debate had the unintended consequence of "provid[ing] an effective and clear method by which the very nature of sociology could be defined. Sociology was an academic discipline which through the intellectual interaction with Marxism produced a distinctive perspective on the structure of industrial capitalist society, generated a clear view of historical development, embraced a sociological approach to ontology and had a philosophy of social science which provided the philosophical framework for empirical social research. Weber's social theory provided contemporary sociology with a systematic 
all divisions between sociologists by emphasizing our common task - to challenge any given state of affairs by critical examination with illustrative examples and convincing metaphors. For example, as Allen rightly notes, today the general trends of contemporary social science - the focus on how reality is constructed through interpretations and meanings and demand for value-free sociologists - divert our attention from the objective contradictions at the heart of social structure and do not encourage a critical or negative judgement of one's society. Such a common task also implies that we have to critically consider our sociological canon, which does not deny any of Weber's significant insights into the workings of society or sociological methodology, but demands seeing him as an outstanding scientist of a particular historical period that inevitably affected his outlook and determined his political views.

The book has the key feature of a good sociological work - it raises more questions on the state and possibilities of sociology in our strange contemporary world, which produces tremendous inequalities and unhappiness on a scale never dreamt of before, than provides answers and recommendations on how we should consider the legacy of one of the founding fathers of the discipline. Allen convincingly distinguishes (1) the ideas of Weber which can and should be used in contemporary sociological studies and the ideas which can but should not be applied as politically or methodologically (and historically) biased; and (2) the sources of such biases - those "authentically" Weberian and those constructed subsequently by the selective application of Weber's legacy. Questioning the potential and limits of Weber's "wealth of concepts" for interpreting contemporary society is a rare quality for books on the history of sociological thought despite their crucial importance for the self-identification and self-knowledge of the discipline. The author finishes the book with a very humanistic appeal to the "ivory towers of academia," which is worth all kinds of support - "to lift the shutter and let the light [apparently from "within" the disciple] — and the wind [from its outer social frontiers] — in" (p. 179).

\section{References}

Batygin G.S. (2002) Kariera, etos i nauchnaya biografiya: k semantike avtobiograficheskogo narrativa [Career, Ethos and Scientific Biography: On the Semantics of the Autobiographical Narrative]. Bulletin of the Tyumen State Oil-Gas University, no 20, pp. 106-119. (In Russian)

Berger P. L. (1963) Invitation to Sociology: A Humanistic Perspective, Garden City: Doubleday.

Collins R. (1986) Weberian Sociological Theory, Cambridge: Cambridge University Press. Fairclough N. (1993) Critical Discourse Analysis and the Marketization of Public Discourse: The Universities. Discourse \& Society, vol. 4, no 2, pp. 133-168.

Feyerabend P. (2010) Against Method, London: Verso.

approach to the construction of social theory, an all-embracing vision of history, and a significant body of political theory." 
Lal D. (2004) In Praise of Empires: Globalization and Order, New York: Palgrave Macmillan.

Pomeranz K. (2000) The Great Divergence: China, Europe, and the Making of the Modern World Economy, Princeton: Princeton University Press.

Scaff L. A. (1984) Weber before Weberian Sociology. British Journal of Sociology, vol. 35, no 2, pp. 190-215.

Thévenot L., Boltanski L. (1983) Finding One's Way in Social Space: A Study Based on Games. Social Science Information, vol. 22, no 4-5, pp. 631-68o.

Turner B. S. (1977) The Structuralist Critique of Weber's Sociology. British Journal of Sociology, vol. 28, no 1, pp. 1-16.

Turner B. S. (1999) Classical Sociology, London: SAGE.

Turner B. S. (2002) Max Weber: From History to Modernity, London: Routledge.

Vickery B.C., Vickery A. (1987) Information Science in Theory and Practice, London: Butterworths.

Voronkov V., Deviatko I., Shevchenko O., Ushakin S., Kachanov Y., Oleinik A., Filippov A., Koposov N. (2004) Spor o metodakh [Debate on Methods]. Neprikosnovenny zapas, no 3. Available at: http://www.zh-zal.ru/nz/2004/35 (accessed 22 June 2019). (In Russian)

\title{
Слишком много веберов для одной социологии, или Сколь критично следует читать социологическую классику
}

\author{
Ирина Трочук \\ Доктор социологических наук, ведущий научный сотрудник, Центр фундаментальной социологии, \\ Национальный исследовательский университет «Высшая школа экономики» \\ Ведущий научный сотрудник, Центр аграрных исследований, Российская академия народного хозяйства \\ и государственной службы при Президенте РФ \\ Профессор, кафедра социологии, Российский университет дружбы народов \\ Адрес: ул. Мясницкая, д. 20, г. Москва, Российская Федерация 101000 \\ E-mail: irina.trotsuk@yandex.ru
}

Рецензия: Kieran Allen. Weber: Sociologist of the Empire (London: Pluto Press, 2017). 